Bangladesh Journal of Bioethics 2015; 6(1):15-21

\title{
Human Rights: Illusion or Reality; Theological (Shiite) Perspective
}

\author{
Ali Jamkarani \\ Undergraduate Student, \\ Department of Human Rights \& Theology, Etrat University, Iran \\ Email: ali.agigh@gmail.com, ONLINE1JOURNAL@gmail.com
}

\begin{abstract}
The discussion is based around these issues, history of Human Rights, timeline for Human Rights history, question asked in this regard and enemy and friend of 'human rights'. Describing the problems and its resolve from logical reasoning perspective; intellectual argumentation based on logical reason of, what is universal human right, democracy and illegal wars in the world by super powers as example America? Attempt to describe the inner construction of a human being-perfection-. Introduction to the concept of infallibility in different parts in the article, purify yourself and being purified. What is it, is it possible for a creation named human to be not fallible, is the idea or practicing it impossible or there is a great sphere of being able to practicing it and reaching the status if one finds guidance for the right way with peace and human rights prevailed in the world. Majority of the thought in the text, based on hadith-tradition- from the Prophet of Islam Peace upon Him and His family Ahl al-Bait Peace upon Them.
\end{abstract}

Key words: human right; corruptions; infallibility; spirituality; psychology, fitra-core of human being, democracy; intellect; ignorance; senses; illegal wars

\section{Part 1}

Introduction: What are Human Rights universally? Is, the theoretical and practical perspective in desired subject established in the world? Jack Donnelly has done research in this area, but research material remains intact and untouched in areas such as infallibility; one must reflect and not ignore this concept in planting democracy in world scene by establishing human rights universally through a democratic state with core of human as seed and perfection its fruit; human rights its root, infallibility its trunk and democracy its branches, its leaves righteous deeds.

A main problem is 'unity between humanity' that only can be achieved through putting the concept of infallibility beside the concept of human rights, Justice-Adl, democracy, unity itself, perfection, education and peace to achieve complete perfection in highest decree for the theoretical perspective of 'universal human rights' conceptualization. One of the purposes of this article is to show the theoretical flow in wordings as democracy and human rights that is weaved into the concept of Justice-Adl- one of the pillars of faith in Islam. If the practical perspective does not work properly, the problem is the theoretical side that is imperfect and needs to be, worked on, in new ways to open the doors of practical revolution of human rights in human history. These sources ${ }^{1}$ are glimpses in knowing the concept purely from those who acknowledged the concept! 
History of Human Rights: Human rights have roots old but have recently under this century got more attention and been emphasized in the world stage. If one studies human rights history, generally one discovers a pattern that is, that human rights advanced when humans where in difficulty to find a solution for a problem or because of wars done without firm ground for the cause of war; Example World Wars. Human rights can concern an individual, family and society and implemented in universal scale.

As part of our inner nature; disposition-fitra- humans are bound to be in contact-socialize- with not only their species but all natural creation, everything that Allah has created, above all of it human being and said; you be as a leader on my behalf on earth-khalifatal-Lah. These said, human rights do not concern only human verses one; human individual or oneself, family or society without it concerns also human verses nature-all Allah creation, and obvious human verses the only and only Creator.

Normally if we are alone and go in a jungle, or we feel that we are in the midst of a society but still feeling; one is in jungle with animals, maybe it is difficult to practice and be a leader on earth and follow all the laws that comes with accepting the leadership. Many of those laws one cannot practice or discover it from our natural instincts and disposition that Allah has given us because we do not get the opportunity or success of simply being a human.

We have also it in our nature; that is working as a group, together for an achievement. Doing something together has more chance of success and acceptance than being an alone individual without inspiring the masses. Human being from all times shared responsibilities, duties and rights to each other and from each other. One can find and read some facts about these old texts divine and non-divine, and understand the content of it; of how advanced these were in giving and announcing human rights; The Hindu Vedas, The Babylonian code of Hammurabi, The Holy Bible, The Holy Quran and The Analects of Confucius.

From making and following a timeline about the history of human rights one can see that human rights tendencies grow and become more and more. Different human rights issues arises in the history of mankind or new human rights issues get accepted and implemented in societies when discovered and not invented.

Here follows a simple timeline that one can get help and use it in a research 'hunt', to know human rights history. These are the names of documents in different societies and later global documents. A few personalities are in the timeline 'because of developing human rights' and were active in the field.

For documents what can be interested is why; what for were these documents issued and by who? With other words under what circumstance was, it issued. What is the content of the document, how much of human rights exposed itself by the document? How is there evidence of how the documents implements in the society? Where was the event taken place? When where it taken place; what time in history and a follow up question, in the time it was implemented what was the situation of other nations or societies at that time?

\section{Timeline}

\section{Edicts of Ashoka}

Early poleis of ancient Greece; The Twelve Tables Law

Cyrus Cylinder 6th-539 BC- Century BC 
Risalatul Huquq Imam Zainal Abideen son of Imam al-Hossein Peace upon Them - A Seventh Century Islamic Document on various Legal and Moral Rights of Human Beings. The English translation was done from the original Arabic from Shayakh al-Harrani's book -4th century of Hijra.

Magna Carta 1215 'Great Charter' -habeas corpus-.

Laws of Burgos Age of Discovery 15th and 16th Century

Petition of Right 1628

Bill of rights 1689

US revolution 1776; Virginia Declaration of Rights 1776

US Constitution 1787

French Declaration of the Rights of Man and of the Citizen 1789

US Bill of Rights 1791

John Locke developed the concept of natural law 17th and 18th Century

Native American sources: Inca, Aztec codes of conduct and justice and Iroquois constitution 18th Century

Philosophy of liberalism 18th century Age of Enlightenment

Philosophy: Thomas Paine, John Stuart Mill and G.W.F. Hegel 18th and 19th centuries.

World wars of 20th century Universal Declaration of Human Rights 1948

21th Century Moyn: "The human rights movement expanded beyond its original anti-totalitarianism to include numerous causes involving humanitarianism and social and economic development in the Developing World."

Enemy and Friend of Human Rights: Word human indicates of being in a certain way. When called human and not something else, example animal, plant, mountain, cloud, or letters and numbers, rights come that has to do with human standards and nature, that normally should be considered practical by a human being because it is compatible with the being of a human. One important aspect: that the only human right of being a human is oppressed because when we say human rights, nothing can oppress or take it, even Allah has the power to do it but since it is an act against being just and against his wisdom, God does not commit the act of taking away rights of human beings ${ }^{2}$. The creations are void of intellect and speak in highest decree, like humans; this said nothing has power to take human rights of the humans except themselves. Someone that understands human rights learns it good, memorized it and act upon it with recognition and insight from highest degree of certainty to those rights, maybe that being is a human.

How can it be possible without Ethical morality both inside out in an individual? When individuals practice the outer layer of any religion without understanding and craving for its depth to change them as example: those Muslims that limit religion, to empty ritual acts practically without feeling the delicious taste of worship and tired later, without gaining 'akhlaq', that is observing ethically the boundaries of morality as humans after performing ritual acts prescribed by religion.

Many people may not have belief in the devil and its satanic whispers in the ear that triggers the weak souls, the one sworn enemy of mankind, but they may have belief in the soul "psyche" - "nafs of human being" that said, its nature is disobedience if not trained and hold for that training accountable. The humanity in the same way their bodies are 
different, their souls are different, some are trained and some not in different decrees. These two enemies have two other friends respectively ignorance and corrupt; evil, bad people among the humankind. If one has knowledge of human rights that means one is not ignorant in this regard, but still socialize with corrupt people, will not make the individual to practice it, opposite one learns to use the knowledge against other humans and fight against human rights instead promoting human rights. How can going with corrupt people help one fight and discipline the psyche and being away from whispers of Satan, yes one is away from whispers of the devil in regard that one do not need his whispers when one are in the nest it wants people to be.

Being with corrupt people having diseased souls make even a healthy soul sick and opposite, being with right people, will flourish the soul, as said friends can take you to Hell or Paradise. Reference of these words are the Holy Quran from religion Islam, if we say our heart is locked, dumb, blind and deaf still there is some sense in the Holy verse for us. Its context is; that some people, in the Day of Judgment when asked why they are in Hell, reply comes, because of our friends, we are in Hell; we listened to them.

This said a book is a friend, the classic friend! The book can become a movie that is also a friend, the movie has sound and picture, so pictures are also friend not necessary from that movie in the mind, the sound is friend not necessary from the movie in the mind. Music industry that sings about alcohol, drugs, daily romance dreaming girls and boys, bad language, bad unofficial behavior, and obviously pictures in movies that show blood, killing, immoralities, weapons, drugs, abuse of humans, bad language, fantasy example 'The concept of the worlds end', apocalypse. These are the friends of societies in majority of virtual world on earth and implemented by real corrupt individuals in real world. These virtual friends are corrupt friends and at the same time corruption, right or wrong! Can corrupt people spread physical, virtual and spiritual corruption, through misusing life, technology, sociality, and knowledge "intellect"!

What is corrupt people enjoying or having in their psyche "nafs" that is so dangerous maybe even more than the devil. If we begin from greatest sins that can occupy the soul is; love of this world-material-[that gets born by one having greed and two not having love of the creator in the heart], self-conceit, arrogance, anger, showing off, hypocrisy, hastiness, and wastefulness and so on more concepts of words that go back to their king lgnorance ${ }^{3}$.

If one wants to learn knowledge on a specific field firstly act upon systematic phenomena that is in this case, being away from corrupt people so one gets pure from any symptoms of corrupt people and ready to get knowledge from only the right people. This means before getting knowledge on the field, firstly be with people of knowledge and good will, so being only away from corrupt people is not a help of being away from corruption, only way is to completely change friends and socialize with only people that respect human rights and follow it in their daily life. Than by being with friends, that do always good one can fight individual ignorance and learn necessary knowledge one desires, with intention that increase the intellects power in the mind and by it human gets ready for practicing the good one learns. The knowledge in turn will help in developing the nafs of the human being and used to train for humanity a human; that in turn being human, one can fight the whispers of the devil and oppose it for the cause of human rights universally, differently said evil, wrong and bad thoughts that come in one mind. So purifying is definitely possible to oppose the whispers of the devil, but sometimes still one listens to him but not always in his grip as in past. What is necessary to completely not obey him but instead obey righteous humans and the Creator, only with doing the right thing and practically spreading human rights by action? One purifying method is you purify yourself for the cause of 
human rights that is in the essence-fitra of a human being, waiting to be discovered and touched by a mature intellectual being. However, at this stage of never listening to the devil, happens only by his grace, the creator of the core of human being and all it contains, that The Allah purifies one-the soul- for One -Allah. Except those of your servants among them who are pure (Holy Quran Verse 40 C. 15)

This purity is both sided that said if one loves Allah, Allah loves back, you can't say that you love Allah until One does not love you back, when the loving back happens than it's a love complete both sided and everlasting and known for the concept of love, the same with purity.

How can this be possible if one do not with intellectual honesty have an intention, an intention with desire for the cause? As we have in the book 'Essence of Life' from Allama Majlisi may his soul rest in peace a sentence, mentioned as explanation to the words of Ahl al-Bait-A-, that intention without desire for that intention is useless and desire without intention again not of much use.

Word 'mukhlis,' genitive case in Arabic indicates and means people that have the concept of honesty, sincerity engraved and practicing it to purify themselves, but same word with accusative case 'Mukhlas' means those that are pure, Mukhlas is used in the verse above. "This is because Satanic Temptations have no effect on sincere believers who have put their trust upon God in purifying themselves from the stains of evil" 4 .

It's here that one can understand the necessary importance of a healthy society, always around one, so one is exposed to righteousness than one exposed to corruption. Corruption and righteousness can be in an individual, in society or universally. Universal scale both righteousness and corruption are in fight and which one wins depends on the minor scale wars that are happening in societies around the world and obviously all humanity individually each ONE are in fight for or against righteousness. Corruption as alcohol, cigarette, chunk food with taste but no nutrition and taking advantage of the creation, environment, nature for making money. Using women as ads and products in the name of hiring for jobs of slavery for their body and educational purposes for making money, not to forget modern slavery, money renting, smuggling weapon, smuggling body parts, smuggling drugs, smuggling animals in land and sea for making money, secularity, extremism-radicalism- and capitalism 'obviously' for money making purposes; affects different societies. Doing illegal wars for making money as in Afghanistan, Iraq, Libya, by United States of America! Summary, the media is owned in Europe and America of few, the banks are owned of few [not to mention the system of usury in banking in the world, which even is an infection in ISLAMIC REPUBLIC of Iran banking system, which has infected majority of the population to usury], the knowledge system based on atheist philosophy and of course there can be other corruptive motives involved and helpers maybe.

If there is corruption, there is a corruptive person from humanity and non-humanity only example, the devil, the great evil-doer with ever having highest score, the corrupters are worse than the corruption itself that is happening in society.

Imam Ali Peace upon Him said, 'the doer of evil is worse than the evil itself' 5 .

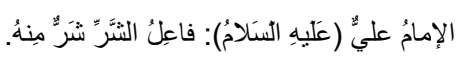

If we take out corruption and not corrupters it may stop corruption from spreading universally; then again the corruption spreads in society of some individuals with those Base inspirations and the effort is only that corruptions 
do not spread universally. The root of corruption can be erased from the surface of the earth by not having corrupters in societies and the seed of corruption can be nullified if all individuals in a society or universally are trained from the best personalities-role models- available, in having human qualities, human training and tame the soul. To spread the righteousness same steps must be taken but opposite direction, that is not stopping righteousness but making it more advanced (See below)

Charter: Every day is Ashura, every land is Karbala; every day is Ashura, every mind/soul is Karbala

Enemies-Corruptors- of human rights:

Friends-righteous- of human rights:

Shaitan the accursed

Prophets \& their Vicegerents; specially Prophet Mohammad \& His 12 Vicegerents from his linage Peace upon Them all

Nafs-soul-

Foolishness; Ignorance

Corrupt people-friends-

Specific corrupt ethical morality

'Love of this World'

General corrupt qualities ex. Wastefulness

Corrupt beliefs, laws, actions

Agnostic World-view
Nafs-soul-

Intellect; Knowledge

Righteous people-friends-

Specific righteous ethical morality 'Love of Allah'

General righteous qualities ex. Frugality

Righteous beliefs, laws, actions

Monotheistic World-view

Ashura, the 10th of Muharram, and Karbala the place of the event! The great sacrifice by the grandson of the last Prophet of Islam Peace upon Him and His Family, against the grandson of Abu Sufyan Curse upon Him, the enemy and further disbeliever in message of Peace. Yazid the unjust ruler, Curse upon Him, wanted to bring forth the era of foolishness and ignorance of the Arabian Peninsula and eradicate Islam from the surface of the earth, sea and sky. The climax of righteousness and corruption! Foolishness and ignorance versus intellect and knowledge! Despite the fact all knowledgeable and intellectual personalities got martyred, thought us a lesson and give life to passion and revolution against the foolish and ignorant tyrants. That there are lines that cannot be crossed by enemies of the Creator Mighty; Wise! The challenge was not Hamans, Pharaohs for Prophet Mosa or Nimrods for Prophet Ibrahim Peace upon them and Curse upon their enemies; it was greater than all the tyrants of history! Yazid Curse upon Him was worse than Pharaoh, Nimrod and Haman.

Each year Muslims commemorate the occasion and millions travel to the tomb of Imam Hossain Peace upon Him. About, more than 20 million Muslims travel to the tomb, which is a great lesson for Justice and Human Rights.

The same, every day for Muslims is like Ashura and the battle ground is their mind where the war of foolishness; ignorance against the intellect; knowledge is happening to have control of us, of our soul, of our psyche. This is called the greater Jihad in Islam; this is how we use word Jihad.

*** This article has two parts. Part $2^{\text {nd }}$ of this article including conclusion and full bibliography will be published in BJB 2015; Vol 6 Issue 2. 


\section{End Note:}

1 http://www.al-islam.org/shiite-encyclopedia-ahlul-bayt-dilp-team: Infallibility of the Prophets Part 1 Part 2 Part 3 , Leadership and Infallibility Part 1 Part 2, The Twelve Imams Part 1 Part 2, The Holy Qur'an and the Pure Imams

2 See bibliography for study material, for purpose of Adl-Justice of God-!

3 "Description on the armies of intelligence and ignorance (jonud aqle va jahle) -by imam khomeini peace upon him.-: This is a valuable book by the Imam on Ethics. The Religious (Kalami) and Ethical opinions and Mysticism of the Imam are more clearly opened in this book and, like his book "the Description on Forty Narratives", more layers (of people) can benefit by it. Currently, the Research Section of the Institute (Qum Branch) is editing the explanatory footnotes and preparing the related lists and other research works, which it will publish, in two volumes of over 800 pages."

Source: http://www.imam-khomeini.com/web1/english/showitem.aspx?cid=1662\&h=13\&f=14\&pid=1794

4 Exegesis-tafsir namonah-, Aya. Makarem, English version, verse 40 chapter 15

5 [Nahj al-Balagha, Saying 32; Scales of Wisdom chapter corruption]

Conflict of interest: No conflict of interest. 